\title{
Effect of Fucoidan on the Regulation of Antioxidant Enzymes in Hepatorenal Tissues of Streptozotocin- Induced Diabetic Rats
}

\author{
DEEPA SOMANATH ${ }^{1 *}$, J. VIJAYAKUMAR, K. V. P. SURIYAKUMARI ${ }^{1}$ AND R. VIJAYARAGHAVAN²
}

Department of Anatomy, Saveetha Medical College, Saveetha Institute of Medical and Technical Sciences, Thandalam, Chennai, Tamil Nadu 600077, ${ }^{1}$ Department of Anatomy, Sri Manakula Vinayagar Medical College and Hospital, Madagadipet, Pondicherry 605107, '2Department of Research and Development, Saveetha Institute of Medical and Technical Sciences, Thandalam, Chennai, Tamil Nadu 600077, India

\section{Somanath et al.: Influence of Fucoidan on Antioxidant Enzymes in Diabetes}

\begin{abstract}
Accumulation of reactive oxygen species resulting from hyperglycemia and inadequate endogenous antioxidants are responsible for the complications of diabetes. Accumulation of reactive oxygen species in the cells stimulates apoptosis, which hampers the cell architecture and functions of vital organs. This study investigates the effect of fucoidan from Sargassum wightii, a potent antioxidant with a regulatory effect on blood glucose homeostasis, in the liver and kidney of diabetic rats. Diabetes was induced in rats by administrating streptozotocin $50 \mathrm{mg} / \mathrm{kg}$ for 3 consecutive days through intraperitoneal injection. $30 \mathrm{male}$ Wistar rats were divided into five groups consisting of six animals in each group and they were Group A: Control group, Group B: Diabetic group, Group C: Diabetic rats treated with metformin hydrochloride $250 \mathrm{mg} / \mathrm{kg}$, Group D: Diabetic rats treated with fucoidan $50 \mathrm{mg} / \mathrm{kg}$, and Group E: Diabetic rats treated with fucoidan $100 \mathrm{mg} / \mathrm{kg}$. Fucoidan was administrated orally for $4 \mathrm{w}$ after the induction of diabetes. Superoxide dismutase activity was low in the liver of the diabetic group and it showed $58.5 \%$ activity, compared with the control group. Fucoidan administration elevated superoxide dismutase and it was $66.5 \%$ and $80.6 \%$ respectively in fucoidan $50 \mathrm{mg} / \mathrm{kg}$ and fucoidan $100 \mathrm{mg} / \mathrm{kg}$ groups, compared with the control group while in the metformin group $93.4 \%$ activity was seen. A similar variation in the superoxide dismutase was observed in the kidney; wherein, administration of fucoidan restored the superoxide dismutase activity and it was $62.9 \%$ in the fucoidan $50 \mathrm{mg} / \mathrm{kg}$ group and $79.5 \%$ in the fucoidan $100 \mathrm{mg} / \mathrm{kg}$ group, compared with the control group while in diabetic group $49.4 \%$ and metformin group 94.2\% activity were observed. The other tested antioxidant enzymes such as catalase, glutathione peroxidase and glutathione $S$ transferase also showed marked regain in a dose-dependent manner upon administration of fucoidan. This study inferred that the administration of fucoidan in streptozotocininduced diabetic rats improved the antioxidant enzyme activity by moderating the accumulation of reactive oxygen species and reduced the pathophysiology.
\end{abstract}

Key words: Diabetes, fucoidan, antioxidant enzymes, free radicals, superoxide dismutase, catalase, glutathione peroxidase, glutathione S-transferase

Diabetes mellitus (DM) causes various complications and has become the major cause of mortality. DM is prone to hyperglycemic pathology due to defects in the vital organs and the associated antioxidant defense system, oxidative stress, damage of cell membranes and subcellular organelles, DNA damage and cell death ${ }^{[1-3]}$. Increased level of free radicals and initiation of oxidative stress leads to the onset of disorders of various organs and body systems. The organs with antioxidant protection are primarily exposed to oxidative damage ${ }^{[4]}$. Natural antioxidants from herbal plants, micro and macroalgae

*Address for correspondence

E-mail: deepa.somanath@gmail.com

November-December 2021 protect these damages and may be an effective, safe and economical alternative therapy for the management of diabetes and organ protection ${ }^{[5]}$. Marine algae are rich in polysaccharides, which account for more than $50 \%$ of the dry weight. Studies have demonstrated

\footnotetext{
This is an open access article distributed under the terms of the Creative Commons Attribution-NonCommercial-ShareAlike 3.0 License, which allows others to remix, tweak, and build upon the work non-commercially, as long as the author is credited and the new creations are licensed under the identical terms
}

Accepted 13 November 2021

Revised 16 June 2021

Received 18 May 2020 Indian J Pharm Sci 2021;83(6):1164-1173 
that marine algal polysaccharides are predominantly sulfated polysaccharides. The antioxidant activity of the sulfated glucan is greater than that of regular glucan ${ }^{[6,7]}$.

Polysaccharides, which belong to a class of essential organic compounds that form the basis of all living creatures are generated by the combination of monosaccharides ${ }^{[8]}$. With advancements in pharmacological research, the activity of the marine algal polysaccharides has become a significant research topic ${ }^{[9,10]}$. Polysaccharides are generally extracted from dietary materials by various physical, chemical or enzymatic methods and are reported to have an antidiabetic effect. Consumption of polysaccharides could alleviate diabetes through actions on gastrointestinal viscosity, gastrointestinal satiety, colon fermentation and prevention of gastrointestinal inflammation ${ }^{[11]}$. Various in vivo and in vitro trials demonstrated that dietary polysaccharides have hypoglycemic, antioxidant and anti-inflammatory effects ${ }^{[12]}$.

Among polysaccharides, sulfated polysaccharides are considered to be an essential class of compounds having innumerable pharmaceutical applications ${ }^{[13,14]}$. Fucoidans are sulfated cell-wall polysaccharides (2351 kDa molecular weight) found mainly in various species of brown seaweeds such as Saccharina japonica, Undaria pinnatifida and Sargassum spp. A variant form of fucoidans has also been found in animal species including sea cucumber ${ }^{[15]}$. Fucoidan has been reported to possess diverse biological activities with potential medicinal values, such as anticoagulant, antitumor, anti-inflammatory, antiviral, anti-aggregation and antioxidant activities ${ }^{[16-18]}$. The principal chemical components of fucoidan polysaccharide are fucose, sulfate along with uronic acid and a small amount of protein. The efficiency of fucoidan as a potential drug depends on its components and its molecular weight. Therefore, they may prevent DM by varied mechanisms. DM is associated with the increased production of Reactive Oxygen Species (ROS), resulting from reduced activity of Superoxide Dismutase (SOD), Catalase (CAT), Glutathione Peroxidase (GPx), Glutathione S-Transferase (GST) and increased activity of lipid hydroperoxidase ${ }^{[19]}$. Therefore, it has been established that a single therapy addressing to control DM-associated hyperglycemia and hyperlipidemia is not sufficient. The addition of antioxidants has added benefits on DM pathogenesis as ROS is profoundly involved in the development of DM, hypertension, hyperglycemia, hyperlipidemia and atherosclerosis ${ }^{[20,21]}$. Considering the above facts, in the present work, the protective effect of fucoidan on antioxidant enzyme markers in Streptozotocin (STZ)induced diabetic rats was investigated.

\section{MATERIALS AND METHODS}

\section{Collection of seaweeds and preparation of seaweed powder:}

The brown seaweed Sargassum wightii (S. wightii) was collected from Mandapam coastal region (Latitude $9.28^{\circ} \mathrm{N}$ and Longitude $79.12^{\circ} \mathrm{E}$ ), Tamil Nadu, India. Soon after collection, the seaweeds were washed in seawater to remove epiphytes and other dust materials. It was transported to the laboratory in a sterile polythene bag, washed with tap water followed by deionized water and dried at room temperature. The dried seaweeds were cut into small pieces of 2 to $3 \mathrm{~cm}$, converted into a fine powder using an electric blender, sieved and stored in an airtight container. The collected seaweed was identified as $S$. wightii by using the seaweed manual ${ }^{[22]}$.

\section{Isolation and purification of fucoidan:}

Fucoidan was isolated and purified following the method described by Yang et al[23]. The dried brown seaweed, S. wightii powder weighing $20.0 \mathrm{~g}$ was treated with 11 of $85 \%$ ethanol with constant stirring and incubated for $12 \mathrm{~h}$ at room temperature to remove pigments and proteins. Then this mixture was washed with acetone and centrifuged at $1800 \times \mathrm{g}$ for $10 \mathrm{~min}$. The supernatant was discarded and the residue was dried at room temperature. From this dried biomass, $5.0 \mathrm{~g}$ was dissolved in $100 \mathrm{ml}$ of distilled water, boiled at $65^{\circ}$ for $1 \mathrm{~h}$ with stirring and the extract was collected. This was done twice and all the collected extracts were pooled. This combined extract was centrifuged at $18500 \times \mathrm{g}$ for $10 \mathrm{~min}$ and the supernatant was collected. To this supernatant, $99 \%$ ethanol was added till $30 \%$ concentration is reached and was incubated at $4^{\circ}$ for $4 \mathrm{~h}$. Then this solution was centrifuged at $18500 \times \mathrm{g}$ for $10 \mathrm{~min}$ and the supernatant was collected. Again $90 \%$ ethanol was added to the supernatant to get a final concentration of $70 \%$ ethanol and reincubated overnight at $4^{\circ}$. Then the solution was filtered through a $0.45 \mu \mathrm{m}$ pore size nylon membrane and the filtrate was washed with $99 \%$ ethanol and acetone, dried at room temperature. The fucoidan thus obtained was stored in an airtight container at room temperature.

The yield of fucoidan obtained was $2.8 \pm 0.2 \%$. Further, the fucose content was analysed by the phenol sulphuric acid method and the sulfate content was analysed by the barium chloride method ${ }^{[24,25]}$. The fucose and 
sulfate contents of fucoidan showed were; $70.5 \pm 2.1 \%$ and $45.0 \pm 1.20$ respectively. A second purification of fucoidan was carried out. For this, $250 \mathrm{mg}$ of extracted fucoidan was dissolved in $25 \mathrm{ml}$ of distilled water and heated under reflux with $0.75 \mathrm{ml}$ of $3.0 \mathrm{M} \mathrm{HCl}$ for $3 \mathrm{~h}$. After cooling, the mixture was centrifuged at $3000 \times \mathrm{g}$ and the supernatant was neutralized with $1.0 \mathrm{M}$ Sodium Hydroxide $(\mathrm{NaOH})$ and poured over $100 \mathrm{ml}$ of ethanol. The resultant precipitate was dissolved in distilled water, freeze-dried, stored in a labeled vial and used for further experimentation.

\section{Experimental animals:}

Wistar rats were procured from Tamil Nadu Veterinary and Animal Sciences University (Chennai, India) weighing about 180-200 g. The rats were housed in standard environmental conditions $\left(24.0 \pm 1^{\circ}\right.$ and humidity of 40 to 60 ) and were exposed to natural day and night cycles. The animals were fed with a standard rodent pellet diet with water ad libitum. All the animals were maintained as per the guidelines of the Institutional Animal Ethics Committee (IAEC) of Sri Manakula Vinayagar Medical College and Hospital (Pondicherry, India) (Approval No: IAEC/SMVMCH/025/2018). All the animal cages were marked and labeled appropriately.

\section{Induction of diabetes:}

After $1 \mathrm{w}$ of acclimatization, the rats were fasted overnight before being injected with STZ. DM was induced by intraperitoneal injection (for $3 \mathrm{~d}$ ) of a freshly prepared solution of STZ $(50 \mathrm{mg} / \mathrm{kg}$ body weight) in $0.1 \mathrm{M}$ citrate buffer at $\mathrm{pH} 4.5$. Rats were treated with a $5 \%$ glucose solution orally for $3 \mathrm{~d}$ to prevent the early phase of STZ-induced hypoglycemia. The blood glucose level in blood samples from the tail vein was measured $48 \mathrm{~h}$ after STZ administration. All experimental animals showed fasting blood glucose of above $200 \mathrm{mg} / \mathrm{dl}$ and were considered as diabetic and included in the study.

30 male Wistar rats were divided into five groups $(n=6$ in each group), Group A: Control Group (CG), Group B: Diabetic Group (DG), Group C: Diabetic rats treated with Metformin hydrochloride $250 \mathrm{mg} / \mathrm{kg}$, Group D: Diabetic rats treated with Fucoidan $50 \mathrm{mg} / \mathrm{kg}$ (FG1) and Group E: Diabetic rats treated with fucoidan 100 $\mathrm{mg} / \mathrm{kg}$ (FG2). Fucoidan was administrated daily for $4 \mathrm{w}$ by the oral route.

After the treatment for $4 \mathrm{w}$, the rats were sacrificed by intraperitoneal injection of an overdose of sodium pentobarbital. The animals were dissected and tissue samples (liver and kidney) were collected and used for further experimentation.

\section{Antioxidant assay:}

Tissues such as liver and kidney (250 $\mathrm{mg}$ each) were collected, sliced into pieces and homogenized individually in buffers ( $\mathrm{pH} 7$ to 8 ) at a low temperature $\left(5-10^{\circ}\right)$ to give $20 \%$ homogenate $(\mathrm{w} / \mathrm{v})$. The homogenates were centrifuged at $3000 \times \mathrm{g}$ for $10 \mathrm{~min}$ at $5^{\circ}$ in a refrigerated centrifuge. The supernatant was collected and used for antioxidants assay. The tissue homogenates were used to determine the concentrations of SOD, CAT, GPx and GST according to the reference methods $s^{[26-29]}$. Further, the protein content present in the liver and kidney was analyzed following the standard method by Lowry et $a l^{[30]}$.

\section{Statistical analysis:}

The results obtained in the present study were statistically analysed for mean, Standard Deviation (SD) and Analysis of Variance (ANOVA) using Statistical Package for the Social Sciences (SPSS) software. The group means were compared by computing the StudentNewman-Keuls test (SNK test). The results were considered statistically significant if the $\mathrm{p}$ value is less than $0.05(\mathrm{p}<0.05)$. For hypothesis testing significance was tested from the CG, from the STZ group (DG) and metformin group and denoted in the figures as ' $a$ ', ' $b$ ' and 'c' respectively.

\section{RESULTS AND DISCUSSION}

The activity of SOD and CAT in the liver and kidney of CG, DG and treatment groups (MfG, FG1 and FG2) are shown in fig. 1. The SOD activity in the liver of CG was $14.84 \pm 0.24$ unit $/ \mathrm{mg}$ protein; whereas in STZ-induced diabetic rats (DG), it was lowered to $7.26 \pm 0.23 \mathrm{unit} / \mathrm{mg}$ protein. In STZ-induced diabetic rats administrated with $50 \mathrm{mg} / \mathrm{kg}$ and $100 \mathrm{mg} / \mathrm{kg}$ of fucoidan (FG1 and FG2), the liver SOD value ameliorated to the normal level and showed as $9.87 \pm 0.29$ and $11.96 \pm 0.29 \mathrm{unit} / \mathrm{mg}$ protein respectively. Further, in the liver of MfG, the SOD value progressed towards the normal level $(13.86 \pm 0.20$ unit/mg protein). A similar finding was noticed for SOD activity in kidney of diabetic rats treated with fucoidan. In kidney, a minimal SOD value of $4.76 \pm 0.18$ unit/mg protein was registered in DG as against the maximum value $(9.64 \pm 0.22 \mathrm{unit} / \mathrm{mg}$ protein) of CG. In fucoidan administrated groups (FG1 and FG2) the SOD values attenuated towards the normal condition. Also, the metformin-administrated diabetic group displayed higher SOD value (9.08 \pm 0.16 unit/mg protein) closer 


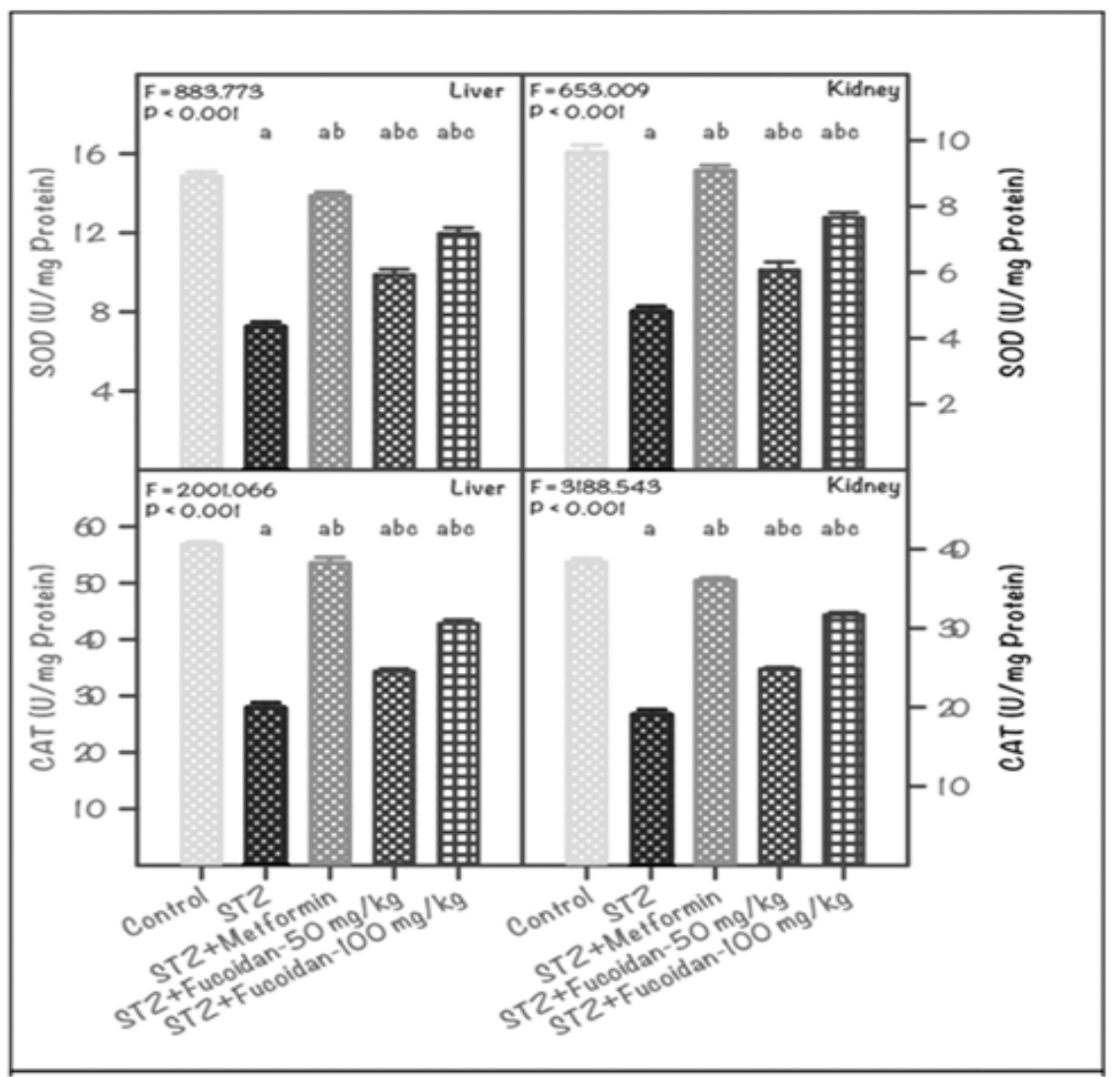

Fig. 1: SOD and CAT activities in the liver and kidney of control, STZ, STZ+metformin, STZ+fucoidan $50 \mathrm{mg} / \mathrm{kg}$ and STZ+fucoidan $100 \mathrm{mg} / \mathrm{kg}$ groups

Note: Values are mean $\pm S D$ ( $n=6$ each). The ' $F$ ' and 'p' values are by one-way ANOVA with SNK multiple comparison test; ${ }^{\text {significantly }}$ different from CG; 'bignificantly different from STZ group (DG); 'significantly different from STZ+metformin group

to CG. In both liver and kidney, the variation in SOD activity between DG and CG, MfG, FG1 and FG2 was statistically significant $(\mathrm{p}<0.01)$.

Furthermore, the CAT activity registered in the liver of DG was very low (27.66 $\pm 0.51 \mathrm{unit} / \mathrm{mg}$ protein), compared to $\mathrm{CG}(56.76 \pm 0.51 \mathrm{unit} / \mathrm{mg}$ protein). Administration of fucoidan at $50 \mathrm{mg} / \mathrm{kg}$ or $100 \mathrm{mg} /$ $\mathrm{kg}$ (FG1 or FG2) restored the liver CAT activity (34.33 \pm 0.50 or $42.80 \pm 0.69$ unit $/ \mathrm{mg}$ protein) compared with DG. Further, in the liver of MfG, the CAT activity registered obvious progress $(53.50 \pm 1.02$ unit/ mg protein), comparable with the values displayed by CG. Likewise, in kidney of DG, a low CAT activity of $19.06 \pm 0.30 \mathrm{unit} / \mathrm{mg}$ protein was recorded, compared with CG. In the kidney of the STZ-induced DG administrated with $50 \mathrm{mg} / \mathrm{kg}$ or $100 \mathrm{mg} / \mathrm{kg}$ of fucoidan (FG1 or FG2), the CAT activity showed restoration and the values recorded were: $24.80 \pm 0.25$ or 31.67 $\pm 0.33 \mathrm{unit} / \mathrm{mg}$ protein, respectively. Also in the kidney of MfG, the CAT activity almost attenuated to near normal level (36.04 \pm 0.33 unit/mg protein), compared with CG. The variation in CAT activity in liver and kidney, between DG and CG, MfG, FG1 and FG2 was statistically significant $(\mathrm{p}<0.01)$.
Further, the present results inferred that the GPx and GST activities in the liver and kidney of STZinduced diabetic rats positively accelerated due to the administration of fucoidan (fig. 2). For instance, in liver of DG, the GPx activity showed a reduction $(5.74 \pm 0.11$ unit/mg protein), compared with CG $(9.82 \pm 0.14$ unit/ $\mathrm{mg}$ protein). Administration of fucoidan either at $50 \mathrm{mg} / \mathrm{kg}$ (FG1) or $100 \mathrm{mg} / \mathrm{kg}$ (FG2) concentrations brought back the activity of GPx to the normal state, to a lesser extent $(6.42 \pm 0.07$ or $7.28 \pm 0.12$ unit $/ \mathrm{mg}$ protein). As expected, the GPx activity in diabetic rats administrated with metformin attained a normal state $(8.98 \pm 0.18$ unit/mg protein). Further, in liver, the variation in GPx activity between CG, DG, MfG and fucoidan-administrated groups (FG1and FG2) was statistically significant $(\mathrm{p}<0.01)$.

The trend recorded for the GPx activity in the kidney of control and experimental rats is similar to that of liver (fig. 2). The GPx activity noticed in CG was high $(8.66 \pm 0.11 \mathrm{unit} / \mathrm{mg}$ protein) and a low value of $4.82 \pm 0.12 \mathrm{unit} / \mathrm{mg}$ protein was recorded in DG. In the diabetic rats administrated with $50 \mathrm{mg} / \mathrm{kg}$ or $100 \mathrm{mg} /$ $\mathrm{kg}$ fucoidan (FG1 or FG2), the GPx activity resumed 


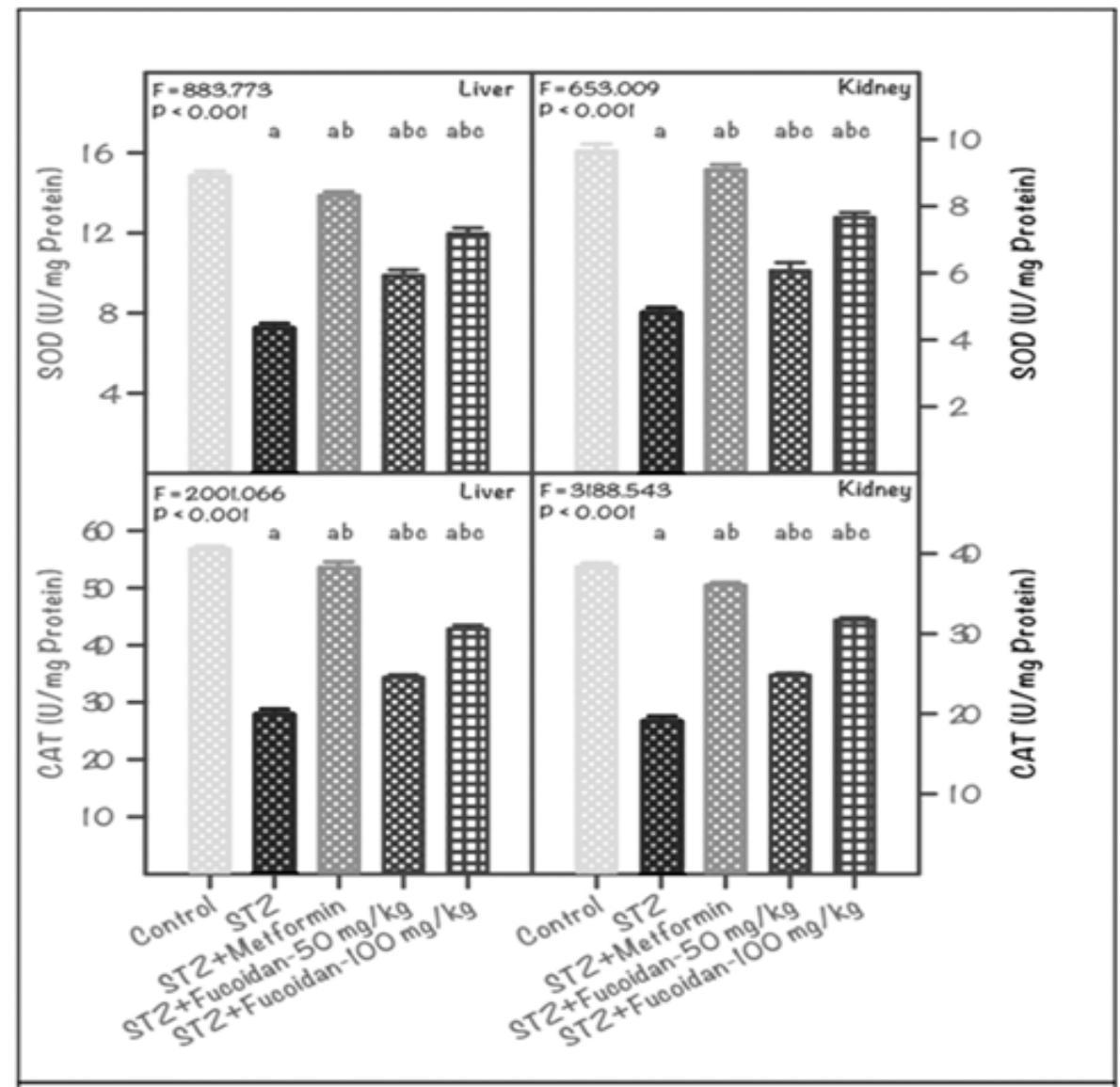

Fig. 2: GPx and GST activities in the liver and kidney of control, STZ, STZ+metformin, STZ+fucoidan $50 \mathrm{mg} / \mathrm{kg}$ and STZ+fucoidan $100 \mathrm{mg} / \mathrm{kg}$ groups

Note: Values are mean \pm SD ( $n=6$ each). The ' $F$ ' and ' $p$ ' values are by one-way ANOVA with SNK multiple comparison test; ${ }^{a}$ significantly different from CG; ${ }^{b}$ significantly different from STZ group (DG); 'significantly different from STZ+metformin group

from the depleted level of DG and the values registered was $5.86 \pm 0.09$ or $6.74 \pm 0.13$ unit/mg protein. The GPx activity of diabetic rats administrated with metformin also attenuated to the normal stage $(8.40 \pm 0.15$ unit/ $\mathrm{mg}$ protein). In the kidney, the variation in GPx activity between DG and CG, MfG, FG1 and FG2 was statistically significant $(\mathrm{p}<0.01)$.

Further, the GST activity in the liver and kidney of STZ-induced diabetic rats was low compared with $\mathrm{CG}$ and other treatment groups (MfG, FG1 and FG2). Accordingly, a higher GST activity (4.63 \pm 0.06 unit/ $\mathrm{mg}$ protein) was registered in the liver of CG; whereas, it was very low $(1.26 \pm 0.03 \mathrm{unit} / \mathrm{mg}$ protein $)$ in $\mathrm{DG}$. However, the GST activity of fucoidan-administrated diabetic rats progressed towards normalization and the values registered were: $1.92 \pm 0.13 \mathrm{unit} / \mathrm{mg}$ protein in FG1 and $2.62 \pm 0.08$ unit $/ \mathrm{mg}$ protein in FG2. Furthermore, the GST activity in the liver of MfG was high (3.94 \pm 0.15 unit/mg protein) compared with DG and the variation between CG, DG and experimental groups was statistically significant $(p<0.01)$ (fig. 2 ).
More or less, a similar variation was registered in the GST activity of kidney of control and experimental groups. For instance, in the kidney of CG, the GST activity registered was $4.03 \pm 0.11 \mathrm{unit} / \mathrm{mg}$ protein and in DG, the GST activity was very low $(0.96 \pm 0.05$ unit/ $\mathrm{mg}$ protein). In fucoidan-administrated diabetic rats, the GST activity registered was $1.34 \pm 0.06$ unit $/ \mathrm{mg}$ protein in FG1 and $1.96 \pm 0.09$ unit/mg protein in FG2. Also in MfG, the kidney GST activity was high $(3.46 \pm 0.32$ unit/mg protein), compared with DG. The variation in GST activity in the kidney of CG, DG and experimental groups (MfG, FG1 and FG2) was statistically significant $(\mathrm{p}<0.01)$ (fig. 2).

DM associated diseases induce several cellular damages through the generation of free radicals and induction of lipid peroxidation resulting in oxidative stress in animals. Arora et al. have reported that injection of rats with STZ resulted in hyperglycemia, probably due to its cytotoxic effect on the $\beta$-cells of the pancreas resulting in insulin deficiency ${ }^{[31]}$. Oxidative stress is implicated in this cytotoxicity. In the present study, the activity of 
SOD in both liver and kidney of STZ-induced diabetic rats was significantly $(\mathrm{p}<0.01)$ reduced when compared to the control and other experimental groups. In specific, in the liver of STZ-induced diabetic rats, the SOD activity retained was $48.9 \%$ and it was almost $50 \%$ low, compared with CG which was in coincidence with the accumulated evidence that STZ caused a great loss in the antioxidant capacity ${ }^{[32]}$. However, administration of $50 \mathrm{mg} / \mathrm{kg}$ (FG1) or $100 \mathrm{mg} / \mathrm{kg}$ (FG2) fucoidan in diabetic rats restored the SOD activity and it was 66.5 $\%$ or $80.6 \%$ compared with CG (fig. $3 \mathrm{~A}$ ).

Furthermore, in the kidney of DG rats, the SOD activity retained was $49.4 \%$ and it was $50 \%$ less than that of the values registered in CG. On the other hand, in fucoidan administrated rats, the SOD activity registered were: $62.9 \%$ (FG1) and $79.5 \%$ (FG2), compared with CG. However, the amelioration of SOD activity due to the administration of fucoidan indicated its efficiency in the restoration of SOD activity at a higher level ( $63 \%$ in FG1 and $80 \%$ in FG2) when compared to a lower level of $50 \%$ in DG (fig. 3B). This study also inferred that the administration of fucoidan alleviated the antioxidant enzyme system by increasing the SOD activity. Chen et al. have reported that low molecular weight fucoidan has great potential as an antioxidant in increasing SOD activity in the acute region of ischemia- reperfusion injury ${ }^{[33]}$. Yu et al. have also reported that low molecular weight fucoidan directly inhibits superoxidase production in high glucose-administrated rat cardiomyocytes ${ }^{[34]}$. However, the antioxidant effect of fucoidan on diabetes-associated hepatic injury remains largely elusive.

The trend noticed for the CAT activity in the liver and kidney of experimental rats was similar to that of SOD activity. In the liver of STZ-induced diabetic rats, the CAT activity retained was $48.9 \%$, compared with CG; whereas, in kidney, it was $49.7 \%$. In both the hepatorenal tissues of diabetic rats received either $50 \mathrm{mg} / \mathrm{kg}$ (FG1) or $100 \mathrm{mg} / \mathrm{kg}$ (FG2) of fucoidan, the CAT showed elevated activity, compared to DG. However, when relating with $\mathrm{CG}$, the CAT activity recorded was $60.5 \%$ or $75.0 \%$ and $64.9 \%$ or $81.8 \%$, respectively in liver and kidney of FG1 or FG2 rats (fig. 3C and fig. 3D). Earlier, Andallu and Voradacharyulu and Bhatia et al. have also reported a notable reduction in CAT activities in the liver and kidney of diabetic rats and inferred that it could be due to increased utilization of these enzymes for scavenging free radicals that emerged during the post-processes of $\mathrm{DM}^{[35,36]}$. Reduced activities of SOD and CAT in plasma and tissues have been observed during diabetes and this may result in several deleterious effects due to the accumulation of superoxide radicals and hydrogen peroxide $\left(\mathrm{H}_{2} \mathrm{O}_{2}\right)^{[36]}$.

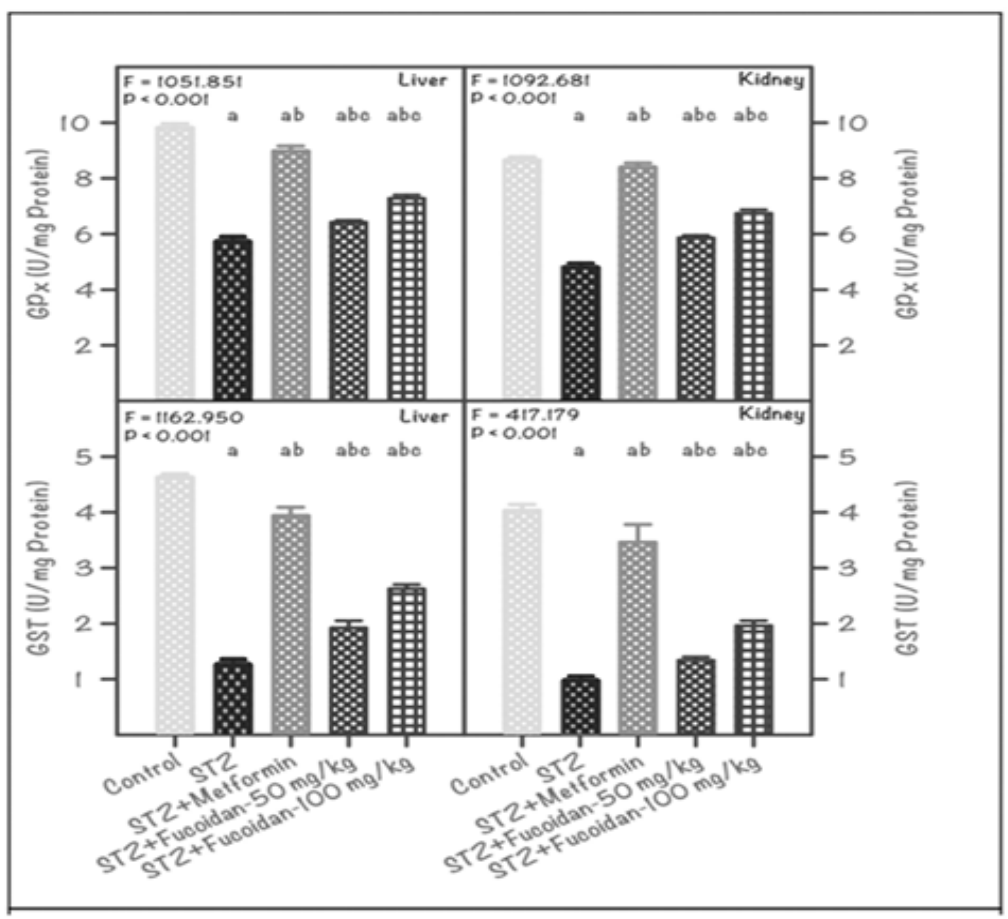

Fig. 3: Percentage activity of SOD and CAT in the liver and kidney of control, STZ, STZ+metformin, STZ+fucoidan $50 \mathrm{mg} / \mathrm{kg}$ and STZ+fucoidan $100 \mathrm{mg} / \mathrm{kg}$ groups

Note: Values are mean \pm SD ( $n=6$ each). The ' $F$ ' and ' $p$ ' values are by one-way ANOVA with SNK multiple comparison test; asignificantly different from CG; 'bignificantly different from DG; 'significantly different from STZ+metformin group 
Zheng et al. have also reported higher hepatic oxidative stress levels with increased superoxide production and lipid peroxidation and decreased hepatic SOD and CAT activities in diabetes-induced mice ${ }^{[37]}$. Further, they have also inferred that the administration of low molecular weight fucoidan measured by ameliorated oxidative stress in the liver of diabetic mice and also accounts for one of the mechanism to protect against liver injury during obese diabetes.

Furthermore, SOD and CAT are the two major scavenging enzymes that remove free radicals in vivo conditions. The decreased activity of these antioxidants can lead to an excess accumulation of superoxide anion $\left(\mathrm{O}_{2}\right)$ and $\mathrm{H}_{2} \mathrm{O}_{2}$, which in turn generate hydroxyl radicals $(\mathrm{OH})$ resulting in initiation and propagation of lipid peroxidation $^{[38]}$. The SOD can catalyze the dismutation of $\mathrm{O}_{2}$ in the $\mathrm{H}_{2} \mathrm{O}_{2}$, which is then deactivated to $\mathrm{H}_{2} \mathrm{O}$ by CAT or SOD. This is in parallel with selenium-dependent GPx, which plays an important role in the reduction of $\mathrm{H}_{2} \mathrm{O}_{2}$ with the presence of reduced glutathione forming oxidized glutathione, which in turn protect cell protein and cell membranes against oxidative stress ${ }^{[39]}$.

In the present study, the administration of fucoidan also enhanced the GPx and GST activities in the hepatorenal tissues of STZ-induced diabetic rats. The GPx activity in the liver of DG was $58.5 \%$, compared with CG; whereas, in the kidney, it was $55.7 \%$ (fig. 4A and fig. 4B), as such the decrease in GPx activity in the hepatorenal tissues ranged from $42 \%$ to $44 \%$. This finding is consistent with the earlier report of Andallu and Varadacharyulu and Bhatia et al. ${ }^{[35,36]}$. They further inferred that the decrease in GPx and GST in STZinduced diabetic rats may be due to the non-availability of its substrate reduced glutathione (GSH), which has been depleted due to the onset of DM-associated diseases ${ }^{[40]}$. DM-associated hyperglycemia and elevated lipid level (lipid peroxidation) result in the generation of ROS, which further promotes oxidative stress. ROS are recognized to play a central role in the pathogenesis of DM-associated complications including non-alcoholic fatty liver, because of their ability to damage DNA, protein and lipids finally resulting in liver dysfunction ${ }^{[41]}$. Furthermore, in this study, in hepatorenal tissues of fucoidan administrated diabetic rats, the GPx activity was restored to a normal level, compared with DG. Accordingly, the GPx activity registered was $65.4 \%$ or $74.2 \%$ and $67.7 \%$ or $77.8 \%$, respectively in liver and kidney of fucoidan fed groups (FG1 or FG2), compared with CG (fig. 4A and fig. 4B). However, it is inferred that, in the fucoidan administrated rats, the restoration of GPx activity ranged from $65 \%$ or $78 \%$ in both the tested tissues. These results inferred that administration of fucoidan at $100 \mathrm{mg} / \mathrm{kg}$ in STZ-induced diabetic rats elevated the GPx activity to a higher level (78\%) which in turn indicated the positive acceleration of the free radical scavenging process in kidney of STZ-induced DMs. It also implies that the administration of fucoidan favors the retrieval of GST activity towards the normal state and thereby promoting the free radical scavenging activity.

In line with the GPx activity, the GST activity in the liver and kidney of STZ-induced DG rats, showed a declining trend and it was $27.2 \%$ in liver and $23.8 \%$ in kidney, compared with CG. In experimental diabetic rats that received fucoidan, the GST activity was restored towards normalization and accordingly, in liver, it was $52.4 \%$ or $107.9 \%$ more, compared with DG. Also in the kidney, the rise in GST activity was $39.6 \%$ or $104.2 \%$ in FG1 or FG2, compared with DG. Moreover, compared with CG, the GST activity was $41.5 \%$ or $56.6 \%$ in liver and $35.3 \%$ or $48.7 \%$ in kidney of FG1 or FG2 (fig. 4C and fig. 4D). The recovery of liver GST activity was more in FG2 and it indicated the potential role played by the fucoidan to restore the GST activity towards normal level and thereby promoting the free radical scavenging activity. In these groups, the GST activity was $39.6 \%$ (FG1) and $104.2 \%$ (FG2) more when compared with the values recorded in DG. GPx is considered a biologically essential enzyme in the reduction of $\mathrm{H}_{2} \mathrm{O}_{2}$. GPx detoxifies peroxides in the presence of reduced $\mathrm{GSH}$, which acts as an electron donor in the reduction process, reducing glutathione disulfide (GSSG) as an end product ${ }^{[42]}$. Further GSHmetabolizing enzymes, GPx and GST work in contact with glutathione in the decomposition of $\mathrm{H}_{2} \mathrm{O}_{2}$ and other organic hydroperoxides to non-toxic products. Reduction in the activities of GPx and GST in the plasma and tissues has been reported during diabetes, which is due to the inactivation of these enzymes by the generation of ROS and this may result in several adverse effects due to the accumulation of free radicals ${ }^{[43]}$.

This present study inferred that administration of STZ in rats, induced oxidative stress in both hepatic and renal tissues through attaining hyperglycemic condition, which is evidenced by the reduced concentration of SOD, CAT, GPx and GST. These results fall in line with the earlier reports of Vipin et al. and AlTrad et al. ${ }^{[44,45]}$. During the hyperglycemic condition, superoxide and nitric oxide react, in the presence of nitric oxide synthase to generate peroxynitrite that 


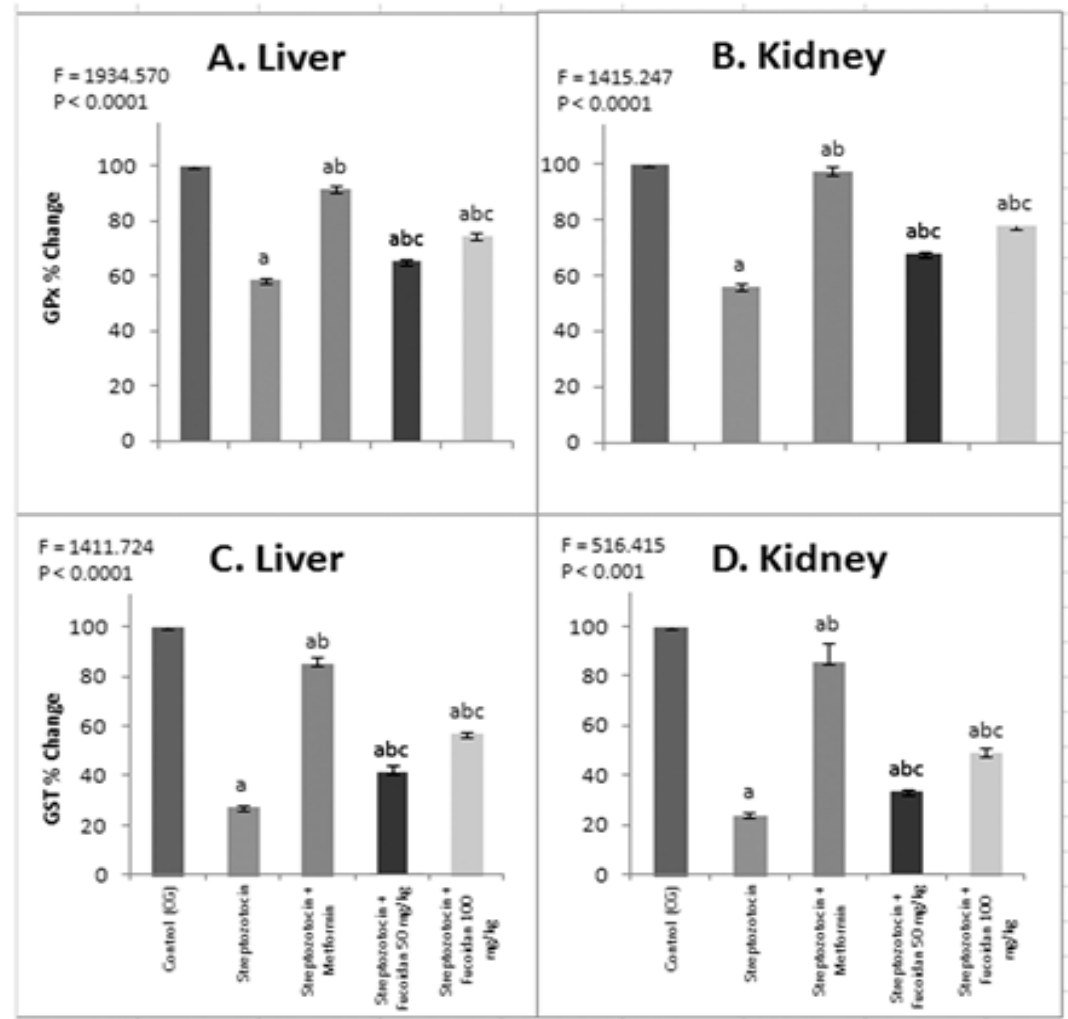

Fig. 4: Percentage activity of GPx and GST in the liver and kidney of control, STZ, STZ+metformin, STZ+fucoidan $50 \mathrm{mg} / \mathrm{kg}$ and STZ+fucoidan $100 \mathrm{mg} / \mathrm{kg}$ groups

Note: Values are mean \pm SD ( $n=6$ each); The ' $F$ ' and ' $p$ ' values are by one-way ANOVA with Student-Newman-Keul's multiple

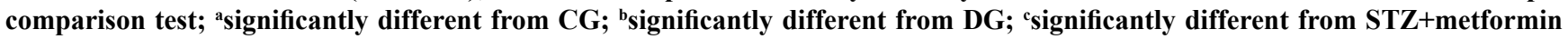
group

injures the cell membrane and cellular biomolecules ${ }^{[46]}$. Furthermore, in experimental rats, administrated with fucoidan, antioxidant activity was elevated through scavenging ROS such as hydroxyl, peroxyl and superoxide radicals and stimulating the activities of SOD, CAT, GPx and GST ${ }^{[34,47,48]}$. Moreover, fucoidan has been shown to suppress the expression of nuclear factor kappa light chain enhancer of activated $B$ cells (NF-kB), protein kinase B, extracellular signalregulating kinase, $\mathrm{C}$-Jun $\mathrm{N}$-terminal kinase and $\mathrm{p} 38$ Mitogen-activated protein kinase ${ }^{[49]}$. Also, it reduced lipopolysaccharide-induced elevation of serum levels of Tumour Necrosis Factor alpha (TNF $\alpha)$, Interleukin 1 beta (IL-1 $\beta$ ) and Interleukin-6 (IL-6) in mice ${ }^{[50]}$. Therefore, it is evident that fucoidan ameliorated DMinduced hepatorenal damages by suppressing oxidative stress by regulating the antioxidant enzyme system ${ }^{[51]}$. Overall, the present results inferred that administration of S. wightii polysaccharide; fucoidan at $100 \mathrm{mg} / \mathrm{kg}$ efficiently suppressed the oxidative stress by enhancing the activity of antioxidant enzymes and thus providing a potential mechanism for relieving the pathogenesis of diabetes.

\section{Acknowledgements:}

The author would like to thank Dr. A. Palavesam, Department of Animal Science, Manonmaniam Sundaranar University, Tirunelveli, Tamil Nadu, India and Dr. S. Ravikumar, Department of Biomedical Science, Alagappa University, Karaikudi, Tamil Nadu, India for their help in the collection, identification of seaweed and extraction of fucoidan.

\section{Conflict of interests:}

The authors declared no conflict of interest.

\section{REFERENCES}

1. Yavuz O, Cam M, Bukan N, Guven A, Silan F. Protective effect of melatonin on $\beta$-cell damage in streptozotocin-induced diabetes in rats. Acta Histochem 2003;105(3):261-6.

2. Tolman KG, Fonseca V, Tan MH, Dalpiaz A. Narrative review: Hepatobiliary disease in type 2 diabetes mellitus. Ann Intern Med 2004;141(12):946-56.

3. Jones AF, Winkles JW, Jennings PE, Florkowski CM, Lunec J, Barnett AH. Serum antioxidant activity in diabetes mellitus. Diabetes Res 1988;7(2):89-92.

4. Mukhamejanov E, Kon G, Erjanova S, Kirgizbaeva A, Muhamadieva E: Fucoidan-New principle prevention and treatment of diabetes. J Pharm Pharmacol 2019;7:316-22. 
5. Cyriac B, Eswaran K. Anti-hyperglycemic effect of aqueous extract of Kappaphycus alvarezii (Doty) Doty ex. P. Silva in alloxan-induced diabetic rats. J Appl Phycol 2016;28(4):250713.

6. Tsiapali E, Whaley S, Kalbfleisch J, Ensley HE, Browder IW, Williams DL. Glucans exhibit weak antioxidant activity, but stimulate macrophage free radical activity. Free Radic Biol Med 2001;30(4):393-402.

7. Ngo DH, Kim SK. Sulfated polysaccharides as bioactive agents from marine algae. Int J Biol Macromol 2013;62:70-5.

8. Sharpatyı̆ VA. Radiochemistry of polysaccharides (review). Radiats Biol Radioecol 1999;39(1):156-61.

9. Itoh $\mathrm{H}$, Noda $\mathrm{H}$, Amano $\mathrm{H}$, Zhuaug $\mathrm{C}$, Mizuno $\mathrm{T}$, Ito $\mathrm{H}$. Antitumor activity and immunological properties of marine algal polysaccharides, especially fucoidan, prepared from Sargassum thunbergii of Phaeophyceae. Anticancer Res 1993;13(6A):2045-52.

10. Mann AJ, Hahnke RL, Huang S, Werner J, Xing P, Barbeyron T, et al. The genome of the alga-associated marine flavobacterium Formosa agariphila KMM 3901T reveals a broad potential for degradation of algal polysaccharides. Appl Environ Microbiol 2013;79(21):6813-22.

11. Hu JL, Nie SP, Xie MY. Antidiabetic mechanism of dietary polysaccharides based on their gastrointestinal functions. J Agric Food Chem 2018;66(19):4781-6.

12. Ganesan K, Xu B. Anti-diabetic effects and mechanisms of dietary polysaccharides. Molecules 2019;24(14):2556.

13. Baba M, De Clercq E, Schols D, Pauwels R, Snoeck R, Van Boeckel C, et al. Novel sulfated polysaccharides: dissociation of anti-human immunodeficiency virus activity from antithrombin activity. J Infect Dis 1990;161(2):208-13.

14. Witvrouw M, De Clercq E. Sulfated polysaccharides extracted from sea algae as potential antiviral drugs. Gen Pharmacol 1997;29(4):497-511.

15. Bilan MI, Usov AI. Structural analysis of fucoidans. Nat Prod Commun 2008;3(10):1639-48.

16. Feldman SC, Reynaldi S, Stortz CA, Cerezo AS, Damonte EB. Antiviral properties of fucoidan fractions from Leathesia difformis. Phytomedicine 1999;6(5):335-40.

17. Richard B, Bouton MC, Loyau S, Lavigne D, Letourneur D, Jandrot-Perrus M, et al. Modulation of protease nexin-1 activity by polysaccharides. Thromb Haemost 2006;95(2):229-35.

18. Cumashi A, Ushakova NA, Preobrazhenskaya ME, D'Incecco A, Piccoli A, Totani L, et al. A comparative study of the antiinflammatory, anticoagulant, antiangiogenic and antiadhesive activities of nine different fucoidans from brown seaweeds. Glycobiology 2007;17(5):541-52.

19. Shi Y, Vanhoutte PM. Oxidative stress and COX cause hyperresponsiveness in vascular smooth muscle of the femoral artery from diabetic rats. Br J Pharmacol 2008;154(3):639-51.

20. Johansen JS, Harris AK, Rychly DJ, Ergul A. Oxidative stress and the use of antioxidants in diabetes: linking basic science to clinical practice. Cardiovasc Diabetol 2005;4(1):5.

21. Li H, Horke S, Förstermann U. Vascular oxidative stress, nitric oxide and atherosclerosis. Atherosclerosis 2014;237(1):20819.

22. Kaliaperumal N, Kalimuthu S, Ramalingam JR. Economically important seaweeds. Central Marine Fisheries Research Institute, special publication; 1995. p. 40-62.

23. Yang N, Zhao M, Zhu B, Yang B, Chen C, Cui C, et al. Antidiabetic effects of polysaccharides from Opuntia monacantha cladode in normal and streptozotocin-induced diabetic rats. Innov Food Sci Emerg Technol 2008;9(4):570-4.
24. Dubois M, Gilles KA, Hamilton JK, Rebers PA, Smith F. Colorimetric method for determination of sugars and related substances. Anal Chem 1956;28(3):350-6.

25. Dodgson KS, Price RG. A note on the determination of the ester sulphate content of sulphated polysaccharides. Biochem J 1962;84(1):106-10.

26. Kakkar P, Das B, Viswanathan PN. A modified spectrophotometric assay of superoxide dismutase. Indian $\mathrm{J}$ Biochem Biophys 1984;21:130-2.

27. Sinha AK. Colorimetric assay of catalase. Anal Biochem 1972;47(2):389-94.

28. Rotruck JT, Pope AL, Ganther HE, Swanson AB, Hafeman DG, Hoekstra W. Selenium: Biochemical role as a component of glutathione peroxidase. Science 1973;179(4073):588-90.

29. Habig WH, Pabst MJ, Jakoby WB. Glutathione S-transferases: The first enzymatic step in mercapturic acid formation. J Biol Chem 1974;249(22):7130-9.

30. Lowry OH, Rosebrough NJ, Farr AL, Randall RJ. Protein measurement with the Folin phenol reagent. J Biol Chem 1951;193:265-75.

31. Arora S, Ojha SK, Vohora D. Characterisation of streptozotocin induced diabetes mellitus in swiss albino mice. Glob J Pharmacol 2009;3(2):81-4.

32. Lenzen S. The mechanisms of alloxan and streptozotocininduced diabetes. Diabetologia 2008;51(2):216-26.

33. Chen X, Tang J, Xie W, Wang J, Jin J, Ren J, et al. Protective effect of the polysaccharide from Ophiopogon japonicus on streptozotocin-induced diabetic rats. Carbohydr Polym 2013;94(1):378-85.

34. Yu X, Zhang Q, Cui W, Zeng Z, Yang W, Zhang C, et al. Low molecular weight fucoidan alleviates cardiac dysfunction in diabetic Goto-Kakizaki rats by reducing oxidative stress and cardiomyocyte apoptosis. J Diabetes Res 2014.

35. Andallu B, Varadacharyulu NC. Antioxidant role of mulberry (Morus indica L. cv. Anantha) leaves in streptozotocin-diabetic rats. Clin Chim Acta 2003;338(1-2):3-10.

36. Bhatia S, Shukla R, Madhu SV, Gambhir JK, Prabhu KM. Antioxidant status, lipid peroxidation and nitric oxide end products in patients of type 2 diabetes mellitus with nephropathy. Clin Biochem 2003;36(7):557-62.

37. Zheng Y, Liu T, Wang Z, Xu Y, Zhang Q, Luo D. Low molecular weight fucoidan attenuates liver injury via SIRT1/ AMPK/PGC1 $\alpha$ axis in $\mathrm{db} / \mathrm{db}$ mice. Int $\mathrm{J}$ Biol Macromol 2018;112:929-36.

38. Rathod N, Raghuveer I, Chitme HR, Chandra R. Free radical scavenging activity of Nyctanthes arbortristis in streptozotocin-induced diabetic rats. Indian J Pharm Educ Res 2010 Jul 1;44(3):288-94.

39. Jin L, Xue HY, Jin LJ, Li SY, Xu YP. Antioxidant and pancreasprotective effect of aucubin on rats with streptozotocin-induced diabetes. Eur J Pharmacol 2008;582(1-3):162-7.

40. Jain SK, Levine SN. Elevated lipid peroxidation and vitamin E-quinone levels in heart ventricles of streptozotocin-treated diabetic rats. Free Radic Biol Med 1995;18(2):337-41.

41. Newsholme P, Haber EP, Hirabara SM, Rebelato EL, Procopio J, Morgan D, et al. Diabetes associated cell stress and dysfunction: role of mitochondrial and non-mitochondrial ROS production and activity. J Physiol 2007;583(1):9-24.

42. Townsend DM, Tew KD, Tapiero H. The importance of glutathione in human disease. Biomed Pharmacother 2003;57(3-4):145-55.

43. Kalaiarasi P, Pugalendi KV. Protective effect of $18 \beta$-glycyrrhetinic acid on lipid peroxidation and antioxidant 
enzymes in experimental diabetes. J Pharm Res 2011;4(1):10711.

44. Vipin AV, Rao R, Kurrey NK, KA AA, Venkateswaran G. Protective effects of phenolics rich extract of ginger against Aflatoxin B1-induced oxidative stress and hepatotoxicity. Biomed Pharmacother 2017;91:415-24.

45. Al-Trad B, Alkhateeb H, Alsmadi W, Al-Zoubi M. Eugenol ameliorates insulin resistance, oxidative stress and inflammation in high fat-diet/streptozotocin-induced diabetic rat. Life Sci 2019;216:183-8.

46. Beckman JS, Koppenol WH. Nitric oxide, superoxide and peroxynitrite: the good, the bad, and ugly. Am J Physiol Cell Physiol 1996;271(5):C1424-37.

47. Rodriguez-Jasso RM, Mussatto SI, Pastrana L, Aguilar $\mathrm{CN}$, Teixeira JA. Chemical composition and antioxidant activity of sulphated polysaccharides extracted from Fucus vesiculosus using different hydrothermal processes. Chem Pap 2014;68(2):203-9.
48. Imbs TI, Skriptsova AV, Zvyagintseva TN. Antioxidant activity of fucose-containing sulfated polysaccharides obtained from Fucus evanescens by different extraction methods. J Appl Phycol 2015;27(1):545-53.

49. Park HY, Han MH, Park C, Jin CY, Kim GY, Choi IW, et al. Anti-inflammatory effects of fucoidan through inhibition of NF$\kappa \mathrm{B}, \mathrm{MAPK}$ and Akt activation in lipopolysaccharide-induced BV2 microglia cells. Food Chem Toxicol 2011;49(8):1745-52.

50. Kuznetsova TA. Fucoidan extracted from Fucus evanescens brown algae corrects immunity and hemostasis disorders in experimental endotoxemia. Bull Exp Biol Med 2009;147(1):669.

51. Aleissa MS, Alkahtani S, Abd Eldaim MA, Ahmed AM, Bungău SG, Almutairi B, et al. Fucoidan ameliorates oxidative stress, inflammation, DNA damage, and hepatorenal injuries in diabetic rats intoxicated with aflatoxin B1. Oxid Med Cell Longev 2020. 